\title{
Kisaran Service Per Conception (S/C) Sapi Peranakan Ongole (PO) di Desa Srimulyo Kecamatan Kalirejo Kabupaten Lampung Tengah
}

\section{Range of Service Per Conception (S/C) on Ongole Cross- Breed Cows in Srimulyo Village, Kalirejo District, Central Lampung Regency}

\author{
Ferry Hernanto \\ Fakultas Peternakan, Universitas Tulang Bawang Lampung, Jl. Gajah Mada, Bandar \\ Lampung \\ hernantferry@gmail.com
}

\begin{abstract}
The research of Service per Conception in Ongole Cross-breed cows in Srimulyo village, Kalirejo District, Central Lampung Regency was conducted in January 2019 until February 2019. The material submitted in the reseach are 200 Ongole Cross-breed cows. The variable research is Service per Conception $(\mathrm{S} / \mathrm{C})$. The method used in this research is to collect primary and secondary data. Analysis data used descriptive and quantitative analysis. The results can be seen that the Service per Conception $(\mathrm{S} / \mathrm{C})$ of Ongole Cross-breed cows in Srimulyo village ranged from 2.36-2.67.
\end{abstract}

Keywords: Ongole Cross-breed Cows, Service per Conception, Srimulyo Village, Value

\section{PENDAHULUAN}

Beternak sapi telah menjadi kebiasaan masyarakat pedesaan pada umumnya yang mempunyai mata pencaharian sebagai petani. Ternak sapi dipelihara untuk dimanfaatkan tenaganya membantu menggarap lahan pertanian, sedangkan kotoran dimanfaatkan sebagai pupuk, sebelum ternaknya diafkir dan dijual sebagai ternak potong.

Berkembangnya wilayah pedesaan menjadi wilayah perkotaan, berpengaruh pada perubahan-perubahan mendasar seperti meningkatnya pengetahuan, pendapatan, kesadaran mencukupi kebutuhan gizi, dan berdampak pada meningkatnya kebutuhan daging yang akan dipenuhi dari berbagai jenis ternak potong. Namun demikian, peternak atau pemasok ternak masih belum dapat mengimbangi permintaan konsumen. Hal ini disebabkan masih terbatasnya populasi sapi potong dan masih ditemukan cara-cara beternak yang mengikuti pola lama atau tradisional, sehingga pertumbuhan ternak cenderung lambat, kurang sehat, dan angka kematian tinggi (Sugeng, 1992). Berdasarkan pertimbangan beberapa permasalahan tersebut diatas perlu dilakukan penelitian pada ternak sapi Peranakan Ongole (PO) di wilayah layanan inseminasi desa Srimulyo Kecamatan Kalirejo Kabupaten Lampung Tengah untuk mengetahui pencapaian angka Service per 
Conception (S/C), dan mengetahui tingkat kesuburan akseptor dengan mempertimbangkan karakterisik peternak (responden) dan reproduksi ternak.

Tujuan dari penelitian ini adalah untuk mengetahui sejauh mana capaian tingkat keberhasilan pelaksanaan Inseminasi Buatan (IB) pada sapi Peranakan Ongole (PO) di desa Srimulyo, Kecamatan Kalirejo, Kabupaten Lampung Tengah dengan menghitung angka Service per Conception (S/C).

\section{MATERI DAN METODE}

\section{Materi}

Materi yang digunakan adalah menghitung kisaran angka $\mathrm{S} / \mathrm{C}$ sebagai ukuran capaian tingkat keberhasilan layanan IB pada ternak sapi lokal Peranakan Ongole (PO) hingga sampai pada tingkat kebuntingan (konsepsi). Penelitian direncanakan pada bulan Januari sampai dengan Februari 2019 atau berlangsung selama 45 hari di desa Srimulyo, Kecamatan Kalirejo, Kabupaten Lampung Tengah.

\section{Alat dan Bahan}

Data sekunder ditabulasikan menggunakan Microsoft Excel 2010 sedangkan analisis data menggunakan Software SAS 9.2 dan Minitab 16.

Bahan yang digunakan dalam penelitian ini berupa 81 ekor sapi FH. Materi yang digunakan terdiri dari data produksi susu (total produksi susu per laktasi), data reproduksi (CI, S/C, dan DO) dari BPTSP-HMT Lembang dan data iklim (curah hujan, suhu, kelembapan, dan THI) tahun 2011-2017 dari BMKG Bogor sebagai BMKG pusat di provinsi Jawa Barat.

\section{Metode}

Metode yang digunakan adalah metode survey. Penyamplingan pada ternak secara acak dan peternak dilakukan secara proporsional. Data yang digunakan adalah data primer dan sekunder. Data primer diperoleh dengan cara mengamati ternak terutama performance ternak, manajemen pemeliharaan sapi Peranakan Ongole (PO) dan melakukan wawancara kepada peternak. Data sekunder diperoleh dari buku dan catatan kartu IB atau recording, sedangkan data-data penunjang lainnya diperoleh dari petugas peternakan Kecamatan dan dari Kabupaten.

\section{HASIL PENELITIAN}

Teknologi Inseminasi Buatan (IB) merupakan alat yang sangat ampuh dalam upaya perbaikan mutu genetik, dan peningkatan populasi ternak. Program inseminasi buatan mulai diperkenalkan di desa Srimulyo pada tahun 2013, dan sejak tahun 2015 masyarakat sudah dapat menerima program inseminasi buatan pada tahapan pengembangan dan mandiri. Dalam pengembangannya program inseminasi buatan belum dapat mencapai tingkat keberhasilan yang optimal. Untuk dapat mencapai keberhasilan IB, banyak faktor yang mempengaruhinya antara lain: (a) kualitas semen (straw) yang digunakan; (b) ketrampilan pelaksana IB; (c) kondisi hewan betina (akseptor) ; (d) ketepatan informasi peternak terkait waktu berahi sapi dan ketepatan waktu IB. 
Untuk dapat mengukur tingkat kesuburan akseptor dan hasil capaian tingkat keberhasilan pelaksanaan inseminasi buatan, salah satunya adalah dengan menghitung Service per Conception (S/C).

Service per Conception (S/C) adalah jumlah pelayanan inseminasi (service) yang dibutuhkan oleh seekor ternak betina sampai terjadinya kebuntingan atau konsepsi (Toelihere, 1981 dan Partodihardjo,1982). Service per Conception juga dapat digunakan untuk menilai efisiensi relatif dari proses reproduksi diantara individu sapi betina yang subur (Toelihere, 1981).

\section{Kisaran Service per Conception (S/C)}

Hasil penelitian yang dilakukan pada akseptor sapi Peranakan Ongole (PO) di Desa Srimulyo, Kecamatan Kalirejo, Kabupaten Lampung Tengah, dapat dilihat pada tabel 2 berikut:

Tabel 1. Hasil Capaian

\begin{tabular}{llllllllll}
\hline \multirow{2}{*}{ Tahun } & \multirow{2}{*}{$\begin{array}{l}\text { Jumlah } \\
\text { Betina }\end{array}$} & \multirow{2}{*}{$\begin{array}{l}\text { Akseptor } \\
\text { Produktif }\end{array}$} & Berahi & \multicolumn{3}{c}{ Pelaksanaan IB } & \multicolumn{2}{c}{ Kebuntingan Hasil IB } & \multirow{2}{*}{ Perhitungan } \\
\cline { 5 - 10 } & & & 1 kali & 2 kali & 3 kali & 1 kali & 2 kali & 3 kali & S/C \\
\hline 2015 & 48 & 35 & 21 & 11 & 3 & 12 & 8 & 2 & 2,36 \\
2016 & 54 & 49 & 26 & 15 & 8 & 18 & 8 & 2 & 2,67 \\
2017 & 66 & 53 & 30 & 17 & 6 & 21 & 9 & 4 & 2,41 \\
2018 & 75 & 63 & 35 & 18 & 10 & 23 & 10 & 5 & 2,66 \\
Jumlah & 243 & 200 & 112 & 61 & 27 & 74 & 35 & 13 & 2,34 \\
Rata-rata & 61 & 50 & 28 & 15 & 7 & 18 & 9 & 3 & 2,52 \\
\hline
\end{tabular}

Dari hasil capaian angka S/C yang dihitung berdasarkan pelaksanaan inseminasi buatan sebanyak 3 kali yang menghasilkan kebuntingan sejak tahun 2015 sampai 2018 diperoleh hasil angka S/C = 2,36 (2015)., 2,67 (2016)., 2,41 (2017)., 2,66 (2018). Capaian angka S/C sebesar 2,36 pada tahun 2015 merupakan capaian angka $\mathrm{S} / \mathrm{C}$ terendah, sedangkan capaian angka S/C 2,67 merupakan capaian angka S/C tertinggi atau dengan kisaran angka S/C sebesar 2,36-2,67. Namun demikian bila dihitung hasil capaian angka S/C selama 4 tahun (2015-2018) diperoleh angka S/C rata-rata $=2,525$ atau dibulatkan menjadi 2,53.

Semen yang digunakan untuk inseminasi buatan di Desa Srimulyo, Kecamatan Kalirejo, Kabupaten Lampung Tengah berasal dari Balai Inseminasi Buatan Lembang, Singosari dan Balai Inseminasi Buatan Daerah Terbanggi Besar, Kabupaten Lampung Tengah. Ditinjau dari aspek kualitas semen yang di produksi Balai Inseminas Buatan tersebut tidak diragukan lagi karena proses produksinya sudah di standarisasi sesuai SNI 01.4869.1.2005. Namun demikian kondisi lapangan dengan segala keterbatasannya dapat menurunkan kualitas semen seperti penyimpanan semen beku dalam kontainer yang berisi N2 cair bertemperatur minus $196^{\circ} \mathrm{C}\left(-196^{\circ} \mathrm{C}\right)$ tidak sempurna dan saat pencairan kembali (thawing) yang tidak sesuai ketentuan dapat merusak straw sehingga sperma dapat menurun motilitasnya dan bahkan dapat mati sebelum di inseminasikan. 


\section{Karakteristik Reproduksi}

Menurut Undang Undang Peternakan dan Kesehatan Hewan yang di maksud dengan akseptor adalah ternak betina produktif yang dimanfaatkan untuk inseminasi buatan. Ternak betina produktif ruminansia seperti sapi dan kerbau, adalah ternak betina yang melahirkan kurag dari 5 (lima) kali atau berumur dibawah 8 (delapan) tahun dengan batasan kisaran umur 2-8 tahun. Ternak-ternak yang digunakan dalam penelitian adalah ternak lokal Peranakan Ongole (PO) yang telah diseleksi sebagai ternak betina produktif dan ditetapkan sebagai akseptor.

Dalam proses reproduksi, setelah sapi betina mengalami pubertas dan berahi, perkembangannya dipengaruhi berberapa faktor seperti keturunan, iklim, sosial, dan makanan (Partodihardjo, 1982). Pengaruh dari berberapa faktor tersebut dapat menyebabkan berahi menjadi tidak normal atau bahkan tidak terjadi berahi. Berahiyang tidak normal menurut Hatmono (2010), diakibatkan adanya gangguan pada ovarium seperti ovarium mengecil (atrofi ovarium), penurunan fungsi ovarium (hypofungsi ovarium), ovarium bersiste (cystic ovarium), dan korpus luteum tetap ada atau bertahan (corpusluteum persisten).

\section{Pengetahuan Peternak Terhadap Berahi}

Sesuai dengan pendapat Toelihere (1981), bahwa tidak mudah untuk menentukan awal berahi pada ternak, maka untuk melaksanakan inseminasi buatan pada ternak dengan mempertimbangkan kondisi lapangan, disarankan observasi atau pengamatan berahi paling sedikit dua kali sehari yaitu pagi hari dan petang hari.Keterlambatan mengawinkan biasanya akibat peternak terlambat melaporkan sapi yang sedang berahi kepada petugas inseminasi (inseminator), deteksi berahi oleh peternak tidak tepat, umur awal kawin (sapi dara), kecukupan gizi sapi betina, kemampuan petugas inseminasi buatan, dan kualitas bibit jantan. Melihat kejadian tersebut, pengamatan atau deteksi berahi pada sapi harus dikuasai peternak agar pelaksanaan program IB berhasil.

\section{Kawin Pertama Pedet}

Hasil penelitian terhadap 46 responden menunjukan bahwa sebanyak 24 responden $(52,18 \%)$ mengawinkan pertama kali pedetnya pada umur 2-3 tahun, 19 responden $(41,30 \%)$ mengawinkan ternak sapinya pada umur kebih dari 3 tahun, dan hanya 3 responden $(5,52)$ mengawinkan ternaknya pada umur kurang dari 2 tahun. Melihat data hasil penelitian sebagian besar petani masih dalam batas wajar atau batas-batas yang dianjurkan.

\section{Kawin Pertama Setelah Beranak}

Calving Interval akan makin panjang dengan bertambahnya jumlah perkawinan yang dapat menghasilkan kebuntingan (Slama et al, 1976 yang disitasi oleh Hartono, 1999). Menurut Hadi dan Ilham (2002), menyatakan bahwa jarak beranak (Calving Interval) adalah 12 bulan, yaitu 9 bulan bunting dan 3 bulan laktasi. Menurut Susilawati dan Affandy (2004), apabila terdapat jarak beranak yang panjang sebagian besar dikarenakanjarak waktu beranak sampai terjadi kebuntingan atau (Days Open) yang panjang. 


\section{Karakteristik Peternak (Responden)}

Umur muda akan lebih bersikap terbuka dan berani untuk mencoba menerapkan perubahan-perubahan teknologi untuk meningkatkan produktivitas usaha ternaknya. Sedangkan umur yang lebih tua cenderung lebih tertutup menerima hal-hal yang bersifat baru untuk pengembangan usaha termasuk penerapan teknologi. Umur mempunyai pengaruh terhadap produktivitas kerja, terutama pada pekerjaan yang mengandalkan tenaga fisik (Saragih, 2000).

Sedangkan peternak yang memiliki pendidikan lebih tinggi, lebih giat mencari informasi-informasi terkait usaha ternak dengan peternak lainya yang lebih maju dan berpengalaman. Sesuai dengan pendapat Sudono et al., (2003) yang menyatakan bahwa salah satu syarat menjadi peternak adalah mempunyai ketekunan bekerja dalam waktu yang lama, serta memiliki motivasi untuk memajukan usaha peternakannya dengan pengelolan yang lebih baik.

\section{Pengalaman Petugas Inseminasi Buatan (Inseminator)}

Dalam menjalankan tugasnya diperlengkapi dengan sarana operasional inseminasi buatan yang terdiri dari kontainer lapangan dengan ukuran 3 liter, N2 cair, insemination gun, pinset, straw, plastic glove, tissue, sabun, gunting, plastic shealth. Saat mencairkan kembali (thawing) semen bekudalam straw menggunakan air sumur dengan waktu 20 detik dengan suhu lingkungan.

\section{KESIMPULAN DAN SARAN}

\section{Kesimpulan}

Dari hasil penelitian yang dilakukan pada ternak sapi Peranakan Ongole (PO) di desa Srimulyo, Kecamatan Kalirejo, Kabupaten Lampung Tengah, dapat disimpulkan bahwa angka Service per Conception (S/C) berkisar antara 2,36-2,67.

\section{Saran}

Untuk dapat meningkatkan keberhasilan inseminasi buatan (IB) disarankan kepada peternak agar selalu menambah wawasan, pengetahuan, dan ketrampilan dalam pengelolaan usaha ternaknya, termasuk penjagaan ternaknya agar selalu sehat dan terhindar dari masalah gangguan reproduksi. Disamping itu masih perlu dilakukan penelitian lebih lanjut terhadap faktor-faktor yang dapat mempengaruhi angka capaian Service per Conception (S/C).

\section{DAFTAR PUSTAKA}

Astuti, M. 2004. Potensi Keragaman Sumberdaya Genetik Sapi Peranakan Ongole (PO). Jurnal wartazoa 14(3) 96-106.

Badan Pusat Statustik Provinsi Lampung. Jumlah Ternak Sapi Di ProvinsiLampung.https://lampung.bps.go.id/linkTableDinamis/view/id/179.

Diakses tanggal 1 Juli 2018. 
Bearden, H. J. And J. W. Fuquay. 1997. Applied Animal Reproduction. 4th ed. PrenticHall Inc., Upper Sadle River, New Jersey.

Direktorat Jenderal Peternakan dan Kesehatan Hewan. 2017. Statistik Peternakan dan Kesehatan Hewan 2017. Kementrian Pertanian. Jakarta.

Direktorat Budidaya Ternak Ruminansia. 2009. Pedoman Umum Pengembangan Alat dan Mesin Inseminasi Buatan dan Unit Layanan Inseminasi Buatan. Direktorat Jenderal Peternakan.

Hardjopranjoto, S. 1995. Ilmu Kemajiran Pada Ternak. Airlangga University Press. Surabaya.

Hartono, M. 1999. Faktor-faktor dan Analisis Garis Edar Selang Beranak pada Sapi Perah di Kecamatan Musuk Kabupaten Boyolali. Tesis. Program Pasca Sarjana. Universitas Gadjah Mada. Yogyakarta.

Hasnawati, M. 2008. Faktor-faktor yang Memperngaruhi Service per Conception pada Sapi Potong di Kecamatan Terbanggi Besar Kabupaten Lampung Tengah. Skripsi. Fakultas Pertanian Universitas Lampung. Bandar Lampung.

Hatmono, Harjuli. 2010. Model Usaha Agribisnis Ternak Sapi Potong. PT. Duta Karya Swasta. Edisi Pertama. Jakarta.

Hunter, R. H. F. 1995. Fisiologi dan Teknologi Hewan Betina Domestik Terjemahan: DK. Harya Putra. Institut Teknologi Bandung. Bandung.

Ihsan, M.N. dan S. Wahjuningsih. 2011. Penampilan Reproduksi Sapi Potong di Kabupaten Bojonegoro. Jurnal Ternak Tropika Vol.12, No.2: 82-87.

Mariyono dan E. Romjali. 2007. Petunjuk Teknis Teknologi Inovasi Pakan murah untuk Usaha Pembibitan Sapi Potong Pusat Penelitian dan Pengembangan Peternakan Pasuruan.

Muladno. 2013. Sapi Indonesia Vs Australia. http://nasional.kompas.com/read/ 2013/07/27/2021358/Sapi.Indoesia.Vs.Australia. Diakses tanggal 8 Juni 2018.

Nata Atmaja D. M. dan J. Arifin. 2008. Karakteristik Ukuran Tubuh dan Reproduksi Pada Kelompok Populasi Domba di Kabupaten Pandeglang dan Garut. Animal Production. Vol 10 (1) hal $140-146$.

Nawawi, H. dan Hadari, Martin M. 1995. Instrumen Penelitian Bidang Sosial. Gajah Mada Universitity Press. Yogyakarta.

Nur Ihsan, M. 1996. Manajemen Reproduksi. Fakultas Peternakan Brawijaya. Malang.

Nuryadi, Wahjuningsih S. 2011. Penampilan Reproduksi Sapi Peranakan Ongole dan Peranakan Limousine di Kabupaten Malang. Jurnal Ternak Tropika. 12(1): 7681.

Partodihardjo, S. 1987. IImu Reproduksi Hewan. Cetakan ke-2. Mutiara Sumber Widya. Jakarta.

Pradhan, R. 2008. Reproductive Disorders in Cattle due to Nutritional Status. Journal of International Development and Cooperation. 14 (1): 45-66. 
Santoso, Urip. 2011. Pentingnya Protein Hewani Asal Ternak Bagi Kesehatan. http://livestock-livestock.blogspot.com./2011/08/pentingnya-protein-hewaniasal-ternak.html?m=1. Diakses tanggal 18 Juni 2018.

Saragih, B. 2000. Agribisnis Berbasis Peternakan. Pustaka Wirausaha Muda. Bogor

Sudono, A., F. Rosdiana, dan B.S. Setiawan. 2003. Beternak Sapi Secara Intensif. Argomedia Pustaka. Jakarta.

Sugeng, Y. B. 1992. Sapi Potong. Cetakan Pertama. Penebar Swadaya. Jakarta.

Sugiyono. 2009. Metode Penelitian Kuantitatif, Kualitatif dan R\&D. Bandung: Alfabet.

Surat Keputusan Menteri Pertanian Nomor: 2841 Tahun 2012. Ciri-ciri Sapi Peranakan Ongole.

Susilawati, T dan Affandi, L, 2004. Tantangan dan Peluang Peningkatan Produktifitas Sapi Potong melalui Teknologi Reproduksi. Loka Penelitian Sapi Potong, Grati, Pasuruan. Fakultas Peternakan, Universitas Brawijaya, Malang.

Statistik Direktorat Jenderal Peternakan dan Kesehatan Hewan. 2017. Direktorat Jenderal dan Kesehatan Hewan. Kementrian Pertanian, Jakarta.

Toelihere, M.R. 1981. Fisiologi Reproduksi Pada Ternak. Penerbit Angkasa: Bandung.

Toelihere, M.R. 1985. Inseminasi Buatan Pada Ternak. Penerbit Angkasa: Bandung.

Toelihere, M.R. 1993. Inseminasi Buatan Pada Ternak. Angkasa. Bandung.

Winugroho. 2002. Strategi Pemberian Pakan Tambahan Untuk Memperbaiki Efisiensi Reproduksi Induk Sapi. Jurnal Litbang Pertanian 21 (1): Bogor. 